Onomastica Slavogermanica

XXXI

Wrocław 2019

DOI: $10.19195 / 0474-1471.31 .3$

\author{
JAROSŁAW MALICKI \\ Wrocław
}

\title{
Zapisy toponimicznych poloników i bohemików wobec zagadnienia powstania i rozwoju polsko-czeskiej granicy językowej w średniowieczu
}

Słowa kluczowe: pogranicze językowe, dialekty śląskie, dialekty śląskomorawskie, toponimia, zapisy toponimów czeskich i polskich

Między polskimi dialektami południowośląskimi a dialektami śląskomorawskimi (laskimi) przebiega najbardziej wyrazisty odcinek historycznej granicy językowej, formowanej w ciągu kilku stuleci na obszarze, na którym przenikały się wpływy i nakładały zasięgi języka polskiego i czeskiego ${ }^{1}$. Czeskie peryferyjne dialekty laskie określane bywały jako dialekty przechodnie ${ }^{2}$, a peryferie

${ }^{1}$ S. Bąk, Mowa polska na Ślaqsku, Wrocław 1974, s. 16, mapa 4, 6; J. Siatkowski, Polsko-czeskie kontakty językowe na terenie Polski, [w:] idem, Czesko-polskie kontakty językowe, Warszawa 1996, s. 187-188; podobnie K. Dejna, Polsko-laskie pogranicze językowe, t. 1-2, Łódź 1951-1953, t. 2, s. 246; por. B. Havránek, Nářeči česká, [w:] Československá vlastivěda. Řada 1., t. 3. Jazyk, s. 212-214, ryc. 13, 14; A. Kellner, Východolašská nářčcí, t. 1-2, Brno 1946-1949, t. 2, s. 45, mapa nr 1. Dialekty laskie (czes. slezskomoravská nářeči) umieszczano na obszarze języka czeskiego (ibidem, t. 2, s. 47; A. Lamprecht, K otázce lašských nářečí, „Slovo a slovesnost” 16, 1955, s. 140-146) lub polskiego (Z. Stieber, Geneza gwar laskich, Kraków 1934)"; por. F. Kopečný, Ještě poznámka k problému česko-polské jazykové hranice, „Slezský sborník” 54, 1956, s. 547-548; por. współczesne tendencje rozwoju polsko-czeskiego pogranicza językowego w pracach J. Damborskiego: Gwara czesko-cieszyńska, [w:] Z badań porównawczych języków i dialektów słowiańskich i niestowiańskich na ziemiach nadodrzańskich, red. J. Brzeziński, Zielona Góra 1992, s. 71-75; idem, Czeszczyzna w pasie przygranicznym, [w:] Konsekwencje sasiedztwa polsko-czeskiego dla rozwoju języka i literatury, red. T.Z. Orłoś, J. Damborský, Wrocław 1997, s. 33-40; idem, Podzwonne dla sporów o laszczyznę, [w:] Podzwonne dla granic. Polsko-czeskie linie podziałów i miejsca kontaktów w języku, literaturze i kulturze, red. J. Lipowski, D. Żygadło-Czopnik, Wrocław 2009, s. 343-351.

${ }^{2}$ S. Bąk, op. cit., s. 157; K. Dejna, op. cit., t. 2, s. 247. Z perspektywy historycznej - na przykład S. Rospond, Problematyka pierwotnych stosunków polsko-czeskich w Bramie Morawskiej, „Kwartalnik Opolski“ 9, 1965, z. 3, s. 38-40, gdzie również odsyłacze do starszej literatury. 
polskiego obszaru południowośląskiego zajmują tak zwane gwary pogranicza polsko-morawskiego ${ }^{3}$. Linia podziału przebiega w przybliżeniu od Baworowa po Bohumín, od Bohumína w kierunku Moravki. Pogranicze językowe, na którym od średniowiecza krzyżowały się zasięgi języka polskiego i czeskiego, rozciąga się więc na zachód i południe od Raciborza, Wodzisławia, Cieszyna, sięga na przedpola Sudetów i Beskidów.

W literaturze dialektologicznej i historycznojęzykowej traktuje się linię Sudetów i Karpat jako umowne odniesienie przestrzenne językowych podziałów już w IX wieku. W mowie zachodnich Słowian zaistniały wówczas dopiero pierwsze znane różnice, które stały się podstawą rozwoju grupy dialektów lechickich (wschodnich i zachodnich), łużyckich i czesko-słowackich. Tym samym w obrębie grup dialektalnych zarysowały się nowe zasady systemowej organizacji jednostek językowych.

Jednak warunki odrębnego rozwoju czeszczyzny i polszczyzny powstały w samodzielnych organizmach politycznych, relatywnie stabilnych od końca $\mathrm{X}$ wieku. Przełom X i XI wieku jest więc początkową cezurą rozwoju areałów użycia obu języków. Odtworzenie pierwotnych zasięgów innowacji lechickich i czesko-słowackich nie jest możliwe, ale najprawdopodobniej w zasięgu władzy monarszej Przemyślidów na bazie zmian czesko-słowackich upowszechniały się innowacje typu czeskiego, w zasięgu władzy Piastów zaś na bazie lechickiej innowacje wschodniolechickie ${ }^{4}$. Prasłowiańszczyzna już nie istniała, nowe języki zaś jeszcze nie wypracowały odrębności systemowej, integralności terytorialnej i funkcjonalnej sprawności. Podstawowe różnice w zasobie środków komunikatywnych jednego początkowo języka (dobrze rozpoznane zwłaszcza na poziomie fonologicznym) ${ }^{5}$ w państwach Piastów i Przemyślidów narastały stopniowo od końca X do końca XIII wieku. Ich przyjęcie stworzyło podstawę gramatycznej i słownikowej odrębności starej czeszczyzny i nieco młodszej od niej staropolszczyzny. Nie jest pewne, czy zmiany te wynikały głównie z częściowo konwergentnego rozwoju dialektów, czy też upowszechniały się na terytoriach państwowych raczej przez oddziaływania administracyjne i misję Kościoła. Wydaje się, że w początkowym stadium języki praczeski i prapolski były w pewnym sensie dialektami ośrodków władzy

Czescy autorzy określali nářčci slezskomoravská także jako pograniczne (pomezní nářeči) — por. A. Kellner, op. cit., t. 1, s. XI; J. Bělič, K otázce pomeznich náreč́i, „Slovo a slovesnost” 16, 1955, s. $129-139$.

${ }^{3}$ S. Bąk, op. cit., mapa 6; w Czechach slezskopolská nářečí traktowano też jako przechodnie (přechodová nářeči), por. A. Kellner, op. cit., s. 60; J. Balhar, Slezská nářeční skupina, [w:] Encyklopedický slovník češtiny, red. P. Karlík, M. Nekula, J. Pleskalová, Praha 2002, s. 399.

${ }^{4}$ Por. Z. Stieber, Zarys gramatyki porównawczej języków słowiańskich, Warszawa 1989, s. 28 59; K. Dejna, Dialekty polskie, Wrocław-Warszawa-Kraków 1993, s. 59-81.

${ }^{5}$ Z. Stieber, Historyczna i wspótczesna fonologia języka polskiego, Warszawa 1966; S. Dubisz, Rozwój polskiego systemu fonologicznego, [w:] Studia z historii języka polskiego, red. W. Kupiszewski, Warszawa 1994, s. 9-19; O. Hujer, Vývoj jazyka československého, [w:] Československá vlastivěda, t. 3. Jazyk, Praha 1934; M. Komárek, Nástin fonologického vývoje českého jazyka, Praha 1982. 
monarszej i duchownej zwierzchności ${ }^{6}$. W każdym razie to w granicach obu monarchii kształtowały się terytorialne zasięgi użycia obu genetycznie pokrewnych i sąsiedzkich języków.

U podnóży Sudetów, w Bramie Morawskiej i na zachodnich peryferiach Karpat nie da się nawet hipotetycznie określić tych zasięgów w X-XII wieku. Nie ma pewności co do tego, że linie wyznaczające zasięg specyficznych dla obu języków cech występowały wspólnie czy choćby w bliskim sąsiedztwie. Zapewne nie było wówczas granicy językowej w rozumieniu dialektologii historycznej jako wiązki izoglos. Wobec przekazów źródłowych o zmiennej przynależności politycznej pogranicza, danych dostarczanych przez archeologów i historyków osadnictwa należy się liczyć z możliwością względnego tylko ustalenia przebiegu izoglos i prawdopodobieństwem ich rozchodzenia się, a więc raczej z pojęciem językowego pogranicza niż granicy?

Do ważniejszych czynników kształtujących charakter omawianego pogranicza należą z pewnością warunki naturalne. Decydowały one o powstaniu rejonów kontaktu (styku i przenikania się zasięgów obu typów innowacji, obu języków) oraz istnieniu terenów izolowanych barierą niezamieszkanych gór i lasów (gdzie zasięgi użycia obu języków były od siebie tak oddalone, jak skupiska osadnicze $)^{8}$. Dogodniejsze warunki komunikacji z sąsiadami z południa miały wspólnoty ulokowane w pobliżu uczęszczanych szlaków (których kontrola stanowiła też obiekt politycznego zainteresowania władców), a więc przy wylocie Bramy Morawskiej, na północ od pasm Niskiego Jesionika i północny wschód od Beskidów Moraw-

${ }^{6}$ B. Havránek wprowadzał tu w latach pięćdziesiątych ubiegłego wieku, nawiązując do polskiej literatury lingwistycznej, pojęcie kulturní jazyk, por. idem, K obecným vývojovým zákonistem spisovných jazyků, [w:] idem, Studie o spisovném jazyce, Praha 1963, s. 92-94; idem, Kotázce mezislovanských vztahů spisovných jazyků, [w:] idem, Studie o spisovném..., s. 332-335. W Polsce o tego rodzaju wczesnych początkach tak zwanego dialektu kulturalnego polszczyzny pisał między innymi S. Urbańczyk, Rozwój języka narodowego, [w:] idem, Szkice z dziejów języka polskiego, Warszawa 1968, s. 30-34; idem, W sprawie polskiego języka literackiego, [w:] idem, Szkice z dziejów..., s. 78-89. B. Walczak zgadza się co do środowiska, z jakiego bierze początek polski standard, jednak pierwszeństwo przyznaje językowi pisanemu, pojęcie dialektu kulturalnego rezerwując dla kulturalnej polszczyzny mówionej na nim opartej — por. B. Walczak, Кoти zawdzięczamy polski język literacki, [w:] Język a chrześcijaństwo, red. I. Bajerowa, M. Karpluk, Z. Leszczyński, Lublin 1983, s. 23-42; idem, Geneza polskiego języka literackiego, „Teksty Drugie: teoria literatury, krytyka, interpretacja" 27,1994, nr 3, s. 35-47.

${ }^{7}$ Wnioski wynikające z ustaleń historyków i archeologów przedstawiłem w artykule Zagadnienie morawskiej i czeskiej obecności na wczesnośredniowiecznym Ślasku jako przesłanka dla lingwistyki historycznej regionu, „Śląski Kwartalnik Historyczny Sobótka” 72, 2017, nr 1 (w przygotowaniu).

${ }^{8}$ Podczas gdy szerokość leśnej rubieży między ustalonymi przez archeologów obszarami plemiennymi na Śląsku i w Czechach wahała się zwykle od 10 do $30 \mathrm{~km}$, to cały graniczny pas karpacko-sudecki w IX-X wieku obejmowała szeroka na około $50-70 \mathrm{~km}$ i gęsto zalesiona strefa pustek osadniczych, rozpoczynając się już na terenach o wysokości ponad $200 \mathrm{~m}$ n.p.m. Zob. mapę Podziały osadniczo-plemienne Stowian zachodnich w VIII-IX w. na wkładce do książki L. Leciejewicza, Stowianie zachodni. Z dziejów tworzenia się średniowiecznej Europy, Wrocław 1989; por. Historia Śląska, t. 1, red. K. Maleczyński, cz. 1, Wrocław 1960, s. 149-152. 
sko-Śląskich i może również na środkowym odcinku Przedgórza Sudeckiego w pobliżu starej drogi przez Przełom Bardzki i Kotlinę Kłodzką do odleglejszych skupisk w Czechach wschodnich i środkowych ${ }^{9}$. Część badaczy dziejów języka polskiego, biorąc pod uwagę te fakty, zawężała kwestię graniczenia obu języków do tych dwu obszarów. Stanisław Urbańczyk na przykład w 1946 roku stwierdzał, że „o bezpośrednim zetknięciu się ludności polskiej i czeskiej można mówić tylko na dwóch stosunkowo krótkich odcinkach: Bramy Morawskiej i Kłodzkiej. Pomiędzy nimi oraz na północny zachód od Bramy Kłodzkiej oba narody było oddzielone bezludnym pasmem gór i lasów, który następnie został zalany elementem niemieckim"10. Jest to ujęcie lepsze niż kreślone na mapach granice języków przebiegające nie tylko przez wspomniane przejścia, lecz także po grzbietach Sudetów - oddzielone nimi skupiska osadnicze nie miały wówczas warunków do częstych kontaktów językowych. Uzasadnione ze względu na intensywność kontaktów zawężenie pogranicza usuwa jednak z pola widzenia wiele możliwych, realnych, słabszych oddziaływań obu języków. Ten stan nie był bowiem niezmienny - w następnych stuleciach zalesione pasma górskie pozostawały nadal barierą kontaktów językowych, jednak zasięgi osadnictwa po obu stronach gór stopniowo się rozszerzały ${ }^{11}$. Źródła pisane odnoszące się do obszaru pogranicza od końca XII wieku dokumentują przyrost osad w sąsiedztwie miejsc, w których już wcześniej zaistniały warunki kontaktów językowych ${ }^{12}$, na pozostałych terenach rozwój osadnictwa poświadczony jest w XIII i XIV wieku.

Choć niektóre dokumenty z okresu intensywnej kolonizacji wspominają o języku czy pochodzeniu nowych osadników, podstawowym materiałem językowym, który możemy próbować umieścić na omawianym obszarze, są nazwy własne, przede wszystkim toponimy ze względu na ich właściwości lokalizacyjne ściśle związane z identyfikacją i indywidualizacją oznaczanych obiektów. W pracach, które w dziejach nazw miejscowych uwzględniają ich przydatność dla historii osadnictwa, pojawia się wiele zastrzeżeń odnośnie do tego materiału. Zwraca się uwagę na niekompletność dokumentacji, późne poświadczenia wczesnych nazw i przede wszystkim na formalną różnorodność zapisów, która

${ }^{9}$ Skupisko osadnicze w Kotlinie Kłodzkiej pozostawało zapewne pod wpływem innowacji językowych typu praczeskiego. Była to jednak bardzo mała wspólnota, bez większego znaczenia dla rozwoju kontaktów językowych. Por. zasięg tamtejszego osadnictwa czeskiego do połowy XIII wieku na mapie Mistní jména českého pưvodu na územi Kladska, J. Malicki, Proměnlivé osudy kladských zeměpisných jmen, predevším mistních, [w:] E. Semotanová et al., Kladsko. Historickogeografický lexikon, Praha 2015, s. 64-65.

10 S. Urbańczyk, Czesko-polska granica etniczna w świetle nazw miejscowych, „Sprawozdania z Czynności i Posiedzeń Polskiej Akademii Umiejętności” 47, 1946, nr 1.

11 Zob. A. Boguszewicz, Z badań nad przemianami osadnictwa w Sudetach Ślaskich w XIIXIII w., [w:] Człowiek i środowisko w Sudetach, red. M. Boguszewicz, A. Boguszewicz, D. Wiśniewska, Wrocław 2000, s. 151-168; L. Leciejewicz, op. cit., s. 280-284.

12 Na przykład dokumenty z 1175, 1189 i 1198 roku: Kodeks dyplomatyczny Śląska, t. 1, wyd. K. Maleczyński, Wrocław 1956, nr 55, 67, 77, 78; z 1183: Codex diplomaticus et epistolaris Moraviae (dalej: $C D M$ ), t. 1, red. A. Boček, Olomutii 1836, nr 307. 
domaga się odróżnienia przyzwyczajeń kancelarii i skryptorów, indywidualnych cech poszczególnych dokumentów i właściwości zapisów mających faktyczny związek z lokalnymi stosunkami językowymi ${ }^{13}$. W owej różnorodności należy rozpatrzyć dwie istotne sytuacje. $Z$ jednej strony nazwy lokowanych wówczas osad i innych obiektów, często po raz pierwszy zapisywane albo też właśnie nadawane, w tekstach łacińskich (potem także niemieckich) dokumentów stawały się znacznikami nowej przestrzeni, którą za pomocą wspomnianych aktów prawnych magazynowały w pamięci szerszej wspólnoty komunikacyjnej. Po drugie, zapisy nazw w jakimś stopniu potwierdzają też lokalny uzus omawianych nazw, ich posiadanie i archiwizowanie w pamięci miejscowej wspólnoty ${ }^{14}$. Ta dwoistość świadectwa ma swój aspekt formalny — jeśli pisarz był rodzimym użytkownikiem języka, to zapewne jako człowiek wykształcony miał większą świadomość modelowych cech wspomnianego dialektu centrum władzy ${ }^{15}$, mógł więc zapisywać rodzime wyrazy, kierując się swoją kompetencją i nieco zmieniając ich formę. Jednocześnie nie można wykluczyć powstawania zapisów oddających (nieporadnymi wówczas środkami) cechy postaci nazw używanych w lokalnej wspólnocie, której akt prawny dotyczył. Takie zapisy mają charakter świadectwa przenikania się konkretnych wycinków przestrzeni społecznej i geograficznej, w której język jako instrument komunikacji współtworzy fakty przekształcające krajobraz naturalny w tak zwany krajobraz kulturalny ${ }^{16}$. W tym przypadku zapisy nazw miejscowych na pograniczu językowym stanowią dobry materiał do ustalenia granic w sensie dialektologicznym. Tymczasem w sytuacji przytoczonej wcześniej zapisany materiał nazewniczy może potwierdzać zasięg oddziaływań centralnych, używania języka ośrodka władzy (i warstw wykształconych) w funkcji pomocniczego języka czynności prawnych. Wynik zastosowania takich „normalizowanych” zapisów do badania zasięgu języka (w sensie etnicznym

${ }^{13}$ Por. na przykład H. Borek, Opolszczyzna w świetle nazw miejscowych, Opole 1972, s. $183-$ 184.

14 Por. L. Zabrocki, Zasięgi językowego magazynowania nazw jednostkowych, [w:] Symbolae philologicae in honorem Vitoldi Taszycki, red. S. Hrabec et al., Wrocław 1968, s. 416-424.

15 Por. S. Urbańczyk, $W$ sprawie polskiego języka literackiego..., s. 82-88.

${ }^{16}$ Por. D. Przybytek, Nazewnictwo miejscowe źródlem w regionalnych badaniach geograficzno-historycznych Śląka, [w:] Nazwa dokumentem przeszłości regionu, red. J. Nowosielska-Sobel, G. Strauchold, W. Kucharski, Wrocław 2010, s. 118-120. Pojęciem „linguistic landscape” (pejzaż / krajobraz językowy) obejmuje się język obecny w środowisku (krajobrazie kulturalnym), ale tylko w jego dostrzegalnych manifestacjach pisanych — napisach i znakach rozwieszonych w przestrzeni publicznej (praktycznie w przestrzeni współczesnego miasta) - nie wydaje się jednak, by istnienie faktów językowych w obserwowanej (także za pomocą słuchu) przestrzeni geograficznej podlegało takim ograniczeniom. Słowa i teksty odnajdujemy w niej również bez napisów, a to dzięki wspomnianej już pamięci wspólnoty. Specyficznymi skondensowanymi tekstami jej kultury są nazwy własne, zwłaszcza toponimia. Por. B. Góral, Czym jest pejzaż językowy (linguistic landscape), [w:] Język w poznaniu 2, red. K. Juszczyk et al., Poznań 2011, s. 41-60; J. David, P. Macha, Názvy mist. Pamět', identita, kulturní dědictví, Brno 2014, s. 34-36, 40-43. 
czy narodowym) jest przewidywalny — powinny one (z pewnym dystansem) potwierdzać przebieg granicy państwowej.

W warunkach kontaktu języków forma toponimów jest istotna dla ich funkcji identyfikującej i indywidualizującej. Przybierając postaci typowe dla jednego z języków, nazwy te służą identyfikacji i indywidualizacji konkretnego wycinka przestrzeni pogranicza na zewnątrz etnicznych, państwowych czy językowych wspólnot komunikacyjnych.

Polskie i czeskie nazwy istniejących na obszarze pogranicza osad stanowią tylko część wzmiankowanego w dokumentach materiału nazewniczego — od drugiej ćwierci XIII wieku coraz więcej jest nazw niemieckich. Na wielu zapisach nazw rodzimych język przybyszów z krajów niemieckich również odcisnął swoje piętno. $Z$ całą pewnością jednak polskie i czeskie toponimy wskazują na zbliżanie się areałów obu języków już w drugiej połowie XII wieku, a następnie na ustalanie ich zasięgów po obu stronach stabilizującej się właśnie granicy państwowej.

Mniej więcej od końca XII wieku, kiedy pogranicze golęszyckie w sensie państwowym i kościelnym stało się częścią Moraw ${ }^{17}$, biskupi wrocławscy i książęta opolscy przystąpili do zasiedlania dawnej rubieży golęszycko-opolskiej, in confinio Morauie ${ }^{18}$ - nad Osobłogą, Stradunią i dalej między Odrą a Psiną ${ }^{19}$ : 1212 Glogov (Głogówek; NGŚ III, 47) ${ }^{20}, 1233$ Chisouic (Czyżowice; NGŚ II, 76), 1212 Jerozlauie (Kazimierz; NGŚ IV, 160), 1226 Wroblin (Wróblin; NGŚ XV, 137), 1223 Kozki (Kózki; NGŚ V, 60), 1223 Gozchenchino (Gościęcin; NGŚ III, 74), 1223 Grudina (Grudynia; III, NGŚ 116), 1294 Wronow (Wronin; NGŚ XV, 149), 1283 Cornicz (Kornice; NGŚ V, 151), 1241 Studna, około 1300 Stusona, (Studzienna; część Raciborza; NGŚ XIII, 106), 1243 Suchdol, około 1300 Schuchdol (Sudół, część Raciborza; NGŚ XIII, 114), 1223 Bogdanowo, 1358 villam Bougnou (Bojanów; NGŚ I, 74), 1283 Benchowiche, (Bieńkowice; NGŚ I, 48). Prócz pamiątkowej biskupio-książęcej nazwy Jarosławia - Kazimierza (1198 Jaroslav, 1212 Jerozlauie que nuc Cazemiria dicitur 1223 Kasimir, Kazimierz; NGŚ IV, 160) ${ }^{21}$ dokumentują to zapisy nazw z wyraźniejszymi cechami

17 P. Kouřil, D. Prix, M. Wihoda, Hrady českého Slezska, Brno-Opava 2000, s. 414-415.

18 Schlesisches Urkundenbuch (dalej: SUb), t. 1, red. H. Appelt, Wien-Köln-Graz, 19631971, nr 284.

19 Zob. A. Barciak, Czechy a ziemie poludniowej Polski w XIII oraz w poczatkach XIV wie$k u$, Katowice 1992; J. Rajman, Jarostaw/Kazimierz $i$ Woszczyce — pierwsze fundacje cysterskie w księstwie opolsko-raciborskim (koniec XII i pierwsza połowa XIII wieku), „Śląski Kwartalnik Historyczny Sobótka" 53, 1998, z. 1-2, s. 1-18.

${ }^{20}$ Cytuję w tej pracy głównie zapisy ujęte i zinterpretowane w słownikach toponomastycznych (zob. wykaz na końcu opracowania). Po odtworzonej na podstawie zapisów dokumentarnych formie nazwy podaję w nawiasie jej współczesne brzmienie jako oznaczenie obiektu nazewniczego oraz miejsce w słowniku. Przypadki, gdy zamieszczona w tekście rekonstrukcja nazwy różni się od zaproponowanej w cytowanym słowniku, sygnalizuję skrótem ,por.” umieszczonym po odsyłaczu.

${ }^{21}$ SUb I, nr 143. 
polskiej fonetyki (między innymi TroT, TloT, a zapisane jako an, en, także ar z ps. $r$ twardego i zdyspalatalizowanego, $c<<t$ 'oraz $g$ wobec czes. $h$ ). Por. 1294 Wronow - Wronów (Wronin; NGŚ XV, 149), 1212 Wroblin - Wróblin (Wróblin) ${ }^{22}, 1212$ Ozoblog - Osobłoga (Osoblaha) 23, 1233 Pransinam, 1300 Pramsina - Prężyna (Prężyna; NGŚ XI, 13), 1223 Gozchenchino, 1226 Gossintin - Gościęcin (Gościęcin; NGŚ III, 74), 1223 Karcouo, 1285 Karchowicz - Karchowo, Karchowice (Karchów; NGŚ IV, 145), 1223 Tuardoua - Twardawa (Twardawa) ${ }^{24}$, 1223 Bogdanowo - Bogdanowo (Bojanów; NGŚ I, 74), 1212 Glogov - Gtogów (Głogówek; NGŚ III, 47), 1223 Grudina - Grudynia (Grudynia; NGŚ III, 116), 1233 Gostonia - Gostomia (Gostomia; NGŚ III, 72). W postaci z około 1300 Stusona - Studzona (Studzienna; NGŚ XIII, 106) zapisano przegłos. $e^{\prime}>o$ (por. Kamiona, NGŚ IV, 133), litera $s$ jest substytutem $d z$. Tylko nieliczne zapisy mają cechy odbiegające od oczekiwanych, modelowych dla ówczesnej polskiej fonetyki - częsty na Śląsku przed spółgłoską szczelinową brak oznaczenia nosowości samogłoski (1223 Nacizhlai - Naczęsław, Naczęsławice ${ }^{25}$ ) czy brak przegłosu $\check{e}>a\left(1223\right.$ Zuestoua - Zwiestowa, Zwiastowice; 1225 Bela - Biela, Biała ${ }^{26}$.

Na dawnym obszarze golęszyckim ${ }^{27}$, od Opawy po Głubczyce leżącym już wówczas po stronie morawskiej, zapisy nowych toponimów potwierdzają zagęszczenie sieci osadniczej, przy czym widoczny jest wpływ niemiecki, na przykład: 1183 Hrobnik (Grobniki), 1210 Kneispole (Księże Pole), 1218 Bogdonaue (Bogdanowice), 1224 Gradec, Lubschicz, Andreowicz, Lubomiricz, Crawarn (Hradec

\footnotetext{
22 Ibidem, nr 143, 260.

23 Ibidem, nr 143.

${ }^{24}$ Ibidem, nr 231.
}

25 Ibidem, nr 231. Por. M. Sulisz, Staropolska fonetyka w świetle materiatu onomastycznego do XIV w., Wrocław 1976, s. 27; B. Dunaj, Język polski najstarszej doby piśmiennej (XII-XIII w.), Kraków 1975, s. 51.

${ }^{26}$ SUb I, nr 231, 254. Por. M. Sulisz, op. cit., s. 90-92.

${ }^{27} \mathrm{~W}$ pracach poświęconych toponimii południowego Śląska do areału golęszyckiego zalicza się Opawszczyznę, Głubczyckie, południowy skraj Raciborskiego, morawski klin między Odrą i Ostrawicą oraz Śląsk Cieszyński (por. R. Šrámek, Soustava místních jmen na severovýchodni Moravě a ve Slezsku, „Slezský sborník” 63, 1965, s. 368-397; H. Borek, op. cit.; R. Mrózek, Nazwy miejscowe dawnego Śląska Cieszyńskiego, Katowice 1984). W świetle nowszych ustaleń historyków i archeologów skupisko osadnicze nad Olzą i górną Wisłą do tego kompleksu jednak nie należało - por. J. Bakala, Národnostni a politický vývoj Slovanů v opavském a těšinském Slezsku, Opava 1969, s. 97-99; P. Kouřil, Severni předpoli moravské brány a zásah velkomoravský, [w:] Ślask i Czechy a kultura wielkomorawska, red. K. Wachowski, Wrocław 1997, s. 65. Na Płaskowyżu Głubczyckim między Opolanami a Golęszycami niektórzy badacze lokalizują siedziby Głupczyców, Głopogłów czy Łupigłów (zapis Lupiglaa w tekście tak zwanego Geografa Bawarskiego), w niniejszej pracy obszar ten traktowany jest jako północna peryferia terytorium golęszyckiego. Zob. S. Urbańczyk, Geografa Bawarskiego Lupiglaa-Glupogłowy, „Slavia” 24, 1957, s. 358; J. Tyszkiewicz, Z badań nad wczesnośredniowiecznym osadnictwem górnego dorzecza Odry. Brzmienia pierwotne i umiejscowienie Lupiglaa i Golensizi tzw. Geografa Bawarskiego, [w:] Studia z dziejów osadnictwa, red. A. Płachcińska, t. 1, Warszawa 1963, s. 1-71; D. Třeštík, Počátky Přemyslovců, Praha 2008, s. 65-66. 
nad Moravicí, Głubczyce, Jędrychowice, Ludmierzyce, Kravaře), 1228 Tourchov, Piezhe (Tworków, Pišt') ${ }^{28}, 1265$ de Darcendorf (Darkovice; MJMS I, 171), 1267 Piskerstorph (Piskořov; MJMS II, 247). Osadnictwo rodzime oraz kierowane z Czech i Moraw w XIII i XIV wieku dotarło na północ i północny wschód w bezpośrednie sąsiedztwo granicy śląsko-morawskiej: 1377 Stiboricz (Ściborzyce Małe; NGŚ XIV, 12), 1318 Lisinitcz (Lisięcice; NGŚ VII, 16), 1232 Tesnouo, 1292 Tesnov (Ciesznów; NGŚ XIV, 180), 1303 Bauorov (Baborów; NGŚ I, 17), 1340 Dgehilhau, Dzengilow (Dzielów; NGŚ II, 159), 1270 Tlustemaz (Tłustomosty; NGŚ XIV), 1377 Hraczan (Gródczanki; NGŚ III, 114 ) 1349 Tryboum, 1377 Treboum (Třebom; MJMS II, 613), 1330 Sudcicz, 1349 Zauditz (Sudice; MJMS II, 516), 1347, 1377 Rogaw (Rohov; MJMS II, 373), 1183 Koberic (Kobeřice; MJMS I, 406), 1265 Cranewitz (Krzanowice; NGŚ II, 55), 1256 Bolatiz, 1349 Poleticz (Bolatice; MJMS I, 90), 1288 Bohuslawiz, (Bohuslavice; MJMS I, 86),1302 Borutin, 1373 Borutswerde (Borucin; NGŚ I, 77), 1377 Bolesla (Bolesław; NGŚ I, 75), XIII wieku Had (Hat'; MJMS I, 244), 1424 Owsist (Owsiszcze; NGŚ IX, 117).

Przejściowe czy kontaktowe położenie tego obszaru i zmienne losy polityczne w XI i XII wieku prowadziły tu do nawarstwiania się wpływów językowych, graficzne czy fonetyczne cechy czeskie mogły się więc pojawiać mniej konsekwentnie. W rekonstruowanych z zapisów XIII i XIV wieku brzmieniach odnajdujemy je jednak częściej. Na przykład międzyspółgłoskowe połączenia -ra-, -la(czes. TraT, TlaT< ps. TorT, TolT): 1224 Crauar - Kravař (Krowiarki; NGŚ VI, 48, por.), 1278 Branicz - Branica (Branice; NGŚ I, 91, por.), 1377 Bladin — Vla$d(\text { ěn })_{\text {in }}$ (Włodzienin) ${ }^{29}$. Również ir, yr jako substytut ps. ${ }^{b} r$ jest bardziej typowy dla języka czeskiego (1240 Kyrnov - Krnov, ts.; MJMS I, 253), gdzie zatarła się różnica między twardym i miękkim $r$-sonans (por. 1256 Dirsizlawe - Držislav, Dzierżysław; NGŚ II, 161) ${ }^{30}$. Jako kontynuanty samogłosek nosowych stosuje się czes. u, na przykład: 1224 Lubschicz, 1259 Hlupchyzhc, 1265 Hlupschitz - Hlubčici (Głubczyce; NGŚ III, 49, por.) oraz czes. $a$ [> 'e] < ps. e, na przykład: 1201 Golassizch, 1218 Holachiz, 1213 Golessicensi, 1240 Holaszcensi - Holešici lub Holasovici (Holasovice; MJMS I, 271) ${ }^{31}, 1237$ Holaspiz, 1321 Holoschwitz (Go-

${ }^{28}$ SUb, t. 1, nr 329, 139, 172, 250, 292.

${ }^{29}$ H. Borek, Górny Śląsk w świetle nazw miejscowych, Opole 1988, s. 142. Stanisława Sochacka przytacza późniejsze przykłady, które potwierdzają trwały uzus tych form. Por. eadem, Pogranicze polsko-czeskie w świetle nazw miejscowych (analiza wptywów czeskich), [w:] Stosunki polsko-czeskie, red. M. Lesz-Duk, R.K. Zawadzki, Częstochowa 1997, s. 148-149.

${ }^{30}$ M. Čornejová, Ke grafice bohemik 10.-12. století, „Sborník prací Filozofické fakulty brněnské univerzity, řada A, Lingustica brunensia” 2005, s. 139-141.

31 Według S. Rosponda w nazwie tej nie można rekonstruować pierwotnego -tę-, możliwe jest tylko -lę-, toteż zapisy z $e$ mogą być refleksem wymowy nosowego $e-i d e m, Z$ badań nad stosunkami językowymi polsko-czeskimi do XVI w., „Rozprawy Komisji Językowej WTN” 4, 1963, s. 105. Por. polemiczny artykuł F. Kopečnego, K jazykové přislušnosti Holasiců, „Slezský sborník" 60, 1962, s. 122-125. 
łuszowice; NGŚ III, 66) ${ }^{32}$. Te zapisy reflektują również modelową wówczas, choć na obszarach peryferyjnych opóźnioną czeską zmianę $g>h$. Por. też: 1288 Bohuslawiz - Bohuslavici, (Bohuslavice, MJMS I, 86), Had - Hat' (Hat'; MJMS I, 244), 1377 Hraczan, Hradschan — Hradčany (Gródczanki; NGŚ III, 114). Nietypowe na tym tle $g$ utrzymywało się w zapisach 1241 Grobnigk, 1256 GrobnickGrobniki (Grobniki; NGŚ III, 102); można tu założyć utrwalenie wcześniejszego stanu w zapisach już zniemczonych. Miękkie $t$ ' z tendencją do wymowy asybilowanej $\left(t^{\prime}>\check{c}\right.$ ) oddawane jest dwojako: 1256 Bolatiz, (Bolatice; MJMS I, 90), 1302 Borutin - Borutín (Borucin; NGŚ I, 77), 1232 Tesnouo, 1292 Tesnov - Těšnov (Ciesznów; NGŚ XIV, 180), 1377 Stiboricz - Stibořice (Ściborzyce Małe; NGŚ XIV, 12) - ale w połączeniu št: 1201 Scepanowiche, 1288 Sczepankowitz, 1295 Schepanowitz - Ščepan(k)ovice (Štěpánkovice; MJMS II, 558), 1228, 1270 Pieshe - Pieščě (Píšt'; MJMS II, 249).

Mieszane zapisy czesko-polskie - z konwencjonalnym nieasybilowanym $t^{\prime}$ w zakończeniach, ale też z zachowanym $r$ (z ps. $r^{\prime}$ ), oraz z substytutami samogłosek nosowych (en, in oddające wymowę $e<$ ps. $e$ oraz an oddające wymowę $a<$ ps. o), są zwykle czternastowieczne: 1318 Lisinitcz, 1327 Lysinticz — * Lisętice > Lisięcice (Lisięcice; NGŚ VII, 16), 1377 Posenticz, Postenticz, 1431 Posutycz — *Postętice > Pościęcice > Posutice (Posucice; NGŚ X, 145 por.) ${ }^{33}$; 1377 Tyrmancz — Trmantice, Trmance (Ciermęcice; NGŚ II, 38 por.) ${ }^{34}$. Choć od 1336 roku opawscy Przemyślidzi stali się książętami raciborskimi, potem z księstwem raciborskim połączono wydzielone z opawskiego karniowskie, to jednak założenie polskiego wpływu kancelaryjnego wydaje się ryzykowne. A zatem prezentowane zapisy mogą być odbiciem starszego stanu, dokumentując lokalny uzus podobnie jak 1281 Sanvricz, 1377 Subericz - Ząbrzyce > Zubrice (Zubrzyce; NGŚ XV) ${ }^{35}$, 1340 Dgehilhau, Dzengilow, 1358 Dehilau - Dzięgielów > Děhylov (Dzielów; NGŚ II, 159) ${ }^{36}$.

Jeszcze w XII i w pierwszych dziesięcioleciach XIII wieku na terenach położonych na wschód od dawnego obszaru golęszyckiego nie było chyba kontaktów związanych z bliskością siedzib użytkowników ówczesnej (morawskiej) czeszczyzny i (śląskiej) polszczyzny. Skupisko osadnicze nad Olzą i górną Wisłą zaczęło się rozbudowywać w pobliżu dawnych siedzib w kierunku południowozachodnim

32 Mimo zastrzeżeń dotyczących interpretacji zapisów z a należy ze względu na lokalizację toponimów i kontekst historyczny uznać tu modelowy czeski kontynuant ps. ę. Por. B. Dunaj, Zapożyczenia czeskie w polszczyźnie XII-XIII w., „Zeszyty Naukowe UJ 451, Filologia. Prace Językoznawcze" 52b, 1976, s. 30. Autor precyzuje w artykule zakres występowania bohemizmów graficznych w Polsce południowej w XII i XIII wieku, znacznie ograniczając inne wcześniejsze interpretacje.

${ }^{33}$ S. Sochacka (op. cit., s. 148) interpretuje Posutice jako wtórną nazwę laską.

${ }^{34}$ H. Borek, Górny Śląs..., s. 148-149.

35 Ibidem, s. 186, 299; S. Rospond, Patronimiczne nazwy miejscowe na Ślasku, Wrocław 1964, s. 169.

${ }^{36}$ Starszeństwo cech polskich w zapisach cytowanych w tym akapicie konstatuje H. Borek, Górny Ślask..., s. 299, NGŚ traktuje przytoczone tu postaci jako wtórnie sczechizowane. 
w pierwszej połowie XIII wieku - była to akcja kolonizacyjna kierowana ze strony polskiej ${ }^{37}$, znaczona takimi nazwami, jak: 1227 Orlova - Orlowa (Orlová; MJMS II, 188), 1229 Solza - Solca (Solca, część Karviny; MJMS II, 476); 1229 Uchilsko - Uchylsko (Uchylsko; NGŚ, XIV, 110), 1229 Zukov - Żuków (Žukov; MJMS II, 829). Wyraźne polskie $c$ z asybilowanego $t$ ' ma zapis 1229 Cierlitzko Cierlicko (Těrlicko; MJMS II, 584), poza nim przytoczone zapisy nie manifestują cech polskich lub czeskich. Polskie (?) $g$ pojawia się w nieco późniejszym dokumencie księcia opolskiego, potwierdzającym przebieg granicy śląsko-morawskiej: 1256 Bogun - Boguń, Bogunin (Bohumín; MJMS I, 84, por.), Grussena - Gruszyna / Gruszeń (Hrušov, część Ostravy; MJMS I, 304). Między Olzą a Ostrawicą intensywniejszy przyrost nazewnictwa nastąpił zapewne pod koniec XIII wieku. Dokumentują to zapisy w Księdze uposażeń biskupstwa wrocławskiego. Jak się można spodziewać, znaczna część tych zapisów nie ma cech odróżniających typowych dla modelu polskiego czy czeskiego i nie są one pozbawione rozmaitych usterek: 1305 Bruschowitz (Bruzovice; MJMS I, 118), Domaslawitz (Domaslavice Dolní; MJMS I, 187), Jannutha (Janovice; MJMS I, 342), Radwanowitz (Radvanovice; MJMS II, 354), Sobisonem (Soběšovice; MJMS II, 773), Tessinowitz (Tošanovice; MJMS II, 595), Dobroczemicza (Dobrá; MJMS I, 181), Sedlicz (Sedliště; MJMS II, 427), Conka (Konská, część Třinca; MJMS I, 422), Sucha (Suchá; MJMS II, 518 ${ }^{38}$. Nazwy o słowiańskich brzmieniach są w dokumencie przemieszane z nazwami tworzonymi od niemieckich nazw osobowych i niemieckimi, na przykład: Bertoltowitz (Bartovice; MJMS I, 54), Cuncindorf (Kunčice n. Ostravicí; MJMS I, 472), Dithmari villa (Dětmarovice; MJMS I, 177), Hermannivilla (Heřmanice; MJMS I, 253), Petirswalde (Petřvald; MJMS II, 242), Richiwalde (Rychvald; MJMS II, 405), Ulrici villa (Oldřichovice; MJMS II, 169), Warmnuthowitz (Lhoty Vyšní; MJMS I, 524), Muglin — zapewne z pierwotnego Mogilno miejscowego lub przeniesionego w zniemczonej postaci (Muglinov; MJMS II, 106). Cechy właściwe modelowi polskiemu ma kilka zapisów. Pol. TroT $<$ ps. TorT: Wrothimow - Wrocimów (Vratimov; MJMS II, 744), pol. $a<$ ps. ę: Wandrina Wądrynia (Vendryně; MJMS II, 677), może też Wenceslaowitz - Więcesławice, Węctawice (Václavovice u Frýdku; MJMS II, 654³9); pol. g: Gnoynik — Gnojnik (Hnojník; MJMS I, 266), Grussow - Gruszów (Hrušov część Ostravy; MJMS I, 304); w postaci Treshez jest zapewne ślad pol. — Trzecież ? (Stř́itež; MJMS II, 508, por.). W zapisie Ropiza znajdujemy nazwę bez analogii w toponimii Czech i Moraw - Ropica (Ropice; MJMS II, 377). Kolejne dwa zapisy - Carvina i Gutha - poświadczają na tym terenie nazwy z odległymi analogiami północno-

${ }^{37}$ R. Mrózek, op. cit., s. 10-11.

38 Zapisy cytowane w MJMS z notatek Vincenca Praska poprawiam według edycji Liber fundationis Episcopatus Vratislaviensis, wyd. H. Markgraf, J.W. Schulte, [w:] Codex Diplomaticus Silesiae, XIV, Breslau 1889: Registrum Wyasdense, s. 110-112.

${ }^{39}$ Tak ze względu na lokalnie używane formy gwarowe $V^{\prime}$ inclovice/Vynclovice, które podaje cytowany słownik. 
polskimi i kaszubskimi - Karwina (Karviná; MJMS I, 384-385), Guta (Guty; MJMS I, 234). Z kolei w zapisie Scalicza pojawia się nazwa typowa dla toponimii Czech, Moraw i Słowacji — Skalica (Skalice; MJMS II, 443).

W tym czasie postępowało też osadnictwo północnomorawskie, dochodząc do linii Ostrawicy (i potem ją przekraczając). W drugiej połowie XIII wieku na lewym brzegu Ostrawicy wzmiankowano nazwy, które możemy uznać za czeskie na podstawie kontekstu, choć nie mają kontrastowych czeskich cech fonetycznych, na przykład: 1267 Oztrauiam, 1297 in Ostrauia - Ostrava (Moravská Ostrava; MJMS II, 202), 1267 Poztecoue, 1297 Pazcov - Paskov (Paskov; MJMS II, 222), 1267 Stariz, 1269 de Stariz — Stařič (Staříč; MJMS II, 488-489). Jedynie w zapisie 1294 in Grabow - Grabov/Hrabov (por. 1389 Grabovie, Hrabová; MJMS I, 288) pojawia się $g$ zamiast spodziewanego już $h$. Może to świadczyć o miejscowej wymowie, choć nie można wykluczyć substytucji graficznej.

Po tej stronie granicznej Ostrawicy przyrostowi osad również towarzyszył silny napływ osadnictwa niemieckiego. Obok nowych nazw niemieckich pojawiły się też zapisy w różnym stopniu zniemczone, por. na stronie morawskiej: 1288 Cunczendorff (Kunčičky u Bašky; MJMS I, 473-474), Landek (Landek; MJMS I, 488), 1332, 1294 Pozmansdorff — może przekład czes. Kozlovice (por. 1359 Cozlowicz, Kozlovice; MJMS I, 437), 1320 Nemasklebe, 1359 Leibenhow Nemášchleby (Chlebovice; MJMS I, 317).

Wraz z rozwojem osadnictwa golęszyckiego i morawskiego język czeski wkroczył na niezamieszkane tereny Niskiego Jesionika na zachód od Opawy i na północ od Morawicy. Nazwane po czesku osady w okolicach Bruntálu, Horniego Benešova i Krnova, na wysokości 400-600 m n.p.m, istniały już w pierwszej połowie XIII wieku (a może wcześniej). Część zapisów ich nazw dość wiernie oddaje czeskie postaci fonetyczne. Stczes. $h<g$ : 1224 Hosdnicz - Hvozdnica (Hvozdnice, zanikła wieś; MJMS I, 313); $z^{\prime}<$ ps. $d z^{\natural}: 1270$ - Mezina, 1377 Mezno - Mezina, Mezno (Mezina; MJMS II, 59-60), 1288 Razov - Razov (Razová; MJMS II, 367); $e<$ ps. $e$ (pol. o < e): 1289 Vualen - Uvalen [Hrad] (Úvalno; MJMS II, 417); inne: 1250 Jameniz, 1270 Jemniz — Jamnica (Jamnice; MJMS I, 340), 1250 Sczadec, 1265 Zadech — Sádek (Sádek; MJMS II, 417), 1377 Sosna - Sosnov (Sosnová; MJMS II, 477), 1377 Radin - Radim (Radim, część Krasova; MJMS II, 342), 1377 Sator — Zátor (Zátor; MJMS II, 780). Niektóre zapisy odnoszą się już jednak do niemieckich adaptacji nazw czeskich, co może wskazywać na starsze pochodzenie nazwy czeskiej: 1252 Benesch, 1288 Beneshow - Benešov (Horní Benešov; MJMS I, 61), 1224 Lechsdorff, 1302 Leschowicz - Leskovici (Leskovec nad Moravicí; MJMS II, 499-500), 1288 Milotndorf Milotici ? (Milotice nad Opavou; MJMS II, 73) ${ }^{40}$.

40 W późniejszych wiekach nie były to jednak tereny całkowicie zniemczone, skoro zanotowano postaci: 1377 Henczicz, 1524 Hynczicze (Hynčice; MJMS I, 313), 1494 Czakowa (Čaková; MJMS I, 151), 1566 Malý Vraclav, 1588 Wraclawek (Vraclavek; MJMS II, 739), 1571 Holczowice (Holčovice; MJMS I, 271). Takie zapisy mogą jednakże wynikać z potrzeb komunikacji środkiem reprezentatywnym dla wspólnoty kraju czy państwa — por. J. Malicki, K onymickým stopám jazykové historie okoli Broumovských stěn, „Východočeské listy historické” 34, 2017, s. 16-19. 
Liczne nazwy niemieckie oraz znacznie przekształcone formy rodzimych nazw w dokumentach, które dotyczą miejscowości położonych dalej na północ, gdzie w XIII wieku akcja osadnicza kierowana z Moraw zetknęła się z wysiłkami kolonizacyjnymi podejmowanymi przez władców Opolszczyzny, świadczą o kontakcie trzech języków na tym obszarze. Jako zapisy nazw przejętych do języka niemieckich osadników trzeba traktować zniekształcone postaci: 1251 Hozenpla, Hocemploc (Osoblaha; MJMS II, 197; NGŚ IX, 102) ${ }^{41}, 1267$ Wiztogk (Vysoká; MJMS II, 761) oraz bardziej przejrzyste 1253 Glezin (Klisino; NGŚ V, 15) i może również 1253 Thomaz (Tomice) $^{42}$. Styk językowy polsko-czeski w połowie XIII wieku można w tym regionie uzasadnić przesłankami historycznymi. Na obszarze, ktory zaczęli zasiedlać książęta opolscy, inicjatywę osadniczą rozwinęli wkrótce biskupi morawscy. Już w pierwszych dziesięcioleciach XIII wieku lokowali Osobłogę i Racławice (1252 Razlawiz iuxta Hocenploc ${ }^{43}$ ) i posiadali w okolicy kilka wsi, których nazwy ze względu na historyczny kontekst są świadectwem morawskiego osadnictwa ${ }^{44}$, por.: 1267 Deuziz, 1300 Dewiz - Děvčici (Dívčí Hrad; MJMS I, 290), 1267 Glynik, 1389 Hlinka — Glinik/Hliník (Hliník; MJMS I, 258), 1267 Zadik — Sádek (Sádek; MJMS II, 417), 1267 Paulowiz - Pavlovice (Dolní Povelice; MJMS II, 296-297), 1267 Wiztogk — Vysoká (Vysoká; MJMS II, 761). Od połowy XIII wieku zakładano w tym rejonie już głównie wsie niemieckich osadników ${ }^{45}$, ale po morawskiej stronie znalazły się też osady założone wcześniej w pobliżu granicy przez władców śląskich ${ }^{46}$. Na północ od rejonu Osobłogi, gdzie w pierwszej połowie XIII wieku istniały już polskie wsie (1233 Lubram, Lubrza, NGŚ VII, 33; 1245 Clyzino, Klisino, NGŚ V, 15; 1218 Lofcovici, 1245 Loucowice, Łowkowice, NGŚ VII, 73) ${ }^{47}$, kilka osad w pobliżu Prudnika założyli też czescy Rożembergowie (1259 Cothen, 1302 Kozhenn - Chotěn/

${ }^{41}$ Taka rekonstrukcja nazwy miejscowej ze względu na wcześniejsze zapisy hydronimu: 1107 Vzablace, 1201 Ozoblogam. Relacja substytucyjna miedzy formami Osobłoga i Hotzenplotz jest niezbyt oczywista, etymologia nazwy niejasna i dyskutowana — por. MJMS II, 197-199. Przeważające we wczesnych zapisach połączenie typu TloT nie jest wystarczającym argumentem za pierwszeństwem formy polskiej przed czeską, mieszanie $a$ i $o$ jest bowiem cechą ówczesnej pisowni substytucyjnej. O pierwszeństwie formy polskiej mogą decydować jedynie przesłanki historyczne.

${ }^{42}$ H. Borek, op. cit., s. 184.

43 Codex diplomaticus et epistolaris regni Bohemiae, red. J. Šebánek, S. Dušková (dalej: $C D B)$, t. 4, Pragae 1962, s. 250, por. NGŚ XI, 88.

${ }^{44}$ CDM III, s. 402. Zob. L. Hosák, Středověká kolonizace Osoblažska, „Časopis Slezského muzea“ 14, 1965, seria B: Vědy historické, s. 24.

45 Jednak już w XIII wieku została tu zanotowana słowiańska adaptacja nazwy niemieckiej: 1262 Luptyn - Luptín (Liptaň; MJMS II, 536), w następnych wiekach zapisano także inne czeskie nazwy wsi noszących wcześniej nazwy niemieckie. Por. 1256 Reneuerdostorp, 1389 Reynersdorf - XVI wieku Czemesna, 1580 Trzemessna (Třemešná; MJMS II, 616).

${ }^{46} C D B$, t. 3, Pragae 1962, nr 222, 232, t. 5/1, Pragae 1978, nr 335.

47 Por. $S U b$ t. 2, nr 32. 
Choceň/Chocieñ ${ }^{48}$, Chocim; NGŚ II, por. $)^{49}$, język czeski dotarł tam zapewne nie tylko jako wpływ kancelaryjny, skoro założony chyba jako lokalne centrum osadnicze Prudnik utrwalił w swojej nazwie (1262 Pruthenos ${ }^{50}, 1331$ Prudnik) zbohemizowaną postać rodzimej nazwy rzecznej Prądnik (NGŚ XI, 21). Kilka pobliskich osad miało nazwy o rodzimych brzmieniach: 1285 de Jassona - Jasiona (ts.; NGŚ IV, 76), 1300 Christovitz, 1301 Crischowicz - Krzyż(k)owice (Krzyżkowice; NGŚ VI, 68).

Dalej, w kierunku Wysokiego Jesionika nie znajdujemy już oczywistych bohemików, które mogłyby poświadczyć rozwój czeskojęzycznego osadnictwa kierowanego z Moraw. W granicach dawnego księstwa biskupiego, w pobliżu Jesenika leży jedna z kilku śląskich Czeskich Wsi - 1416 Behemischdorf (Česká Ves; MJMS II, 680); w średniowieczu określeń Bohemus czy Böhme używano jednak także w odniesieniu do niemieckojęzycznych mieszkańców Czech i Moraw $^{51}$. O zapisach nazw, które dotyczą zasiedlenia środkowej części Przedgórza Sudeckiego, pisałem już we wcześniej opublikowanym artykule ${ }^{52}$. Z wyjątkiem dawniej zasiedlonych okolic Barda i Kamieńca na obszar powyżej 220-240 m n.p.m. osadnictwo zaczęło tu wkraczać pod koniec XII wieku i w następnym stuleciu postępowało w górę licznych dopływów Nysy Kłodzkiej, Piławy i Bystrzycy. Bardzo znaczny udział w zasiedleniu tej części Przedgórza mieli przybysze z krajów niemieckich. Jednak w wyniku kolonizacji wewnętrznej pod koniec XIII wieku południowo-zachodni skraj areału występowania rodzimych nazw pod koniec stulecia przekroczył u podnóży Wysokiego Jesionika i w Górach Złotych warstwicę 400 m n.p.m.: 1268 Wisoka, 1310 Hohdorph (Bukovice; MJMS I, 133), 1283 Supikovici, 1305 Supikowitz (Supíkovice; MJMS II, 523), 1263 Skorossonisvilla, 1305 Scoronsdorph (Skorošice; MJMS II, 448, por.), Wylczica (Vlčice; MJMS II, 722), 1296 Gosena, 1320 Gostycz (Gościce/Horní Hoštice; NGŚ III, 73; MJMS I, 284) - u podnóży Gór Bardzkich i Sowich dotarł do wysokości około 350 m n.p.m.: 1228 Budsin (Budzyń, zanikła część. Budzowa; NGŚ I, 121, por.), 1305 Bresnitz (Brzeźnica $\left.{ }^{53}\right), 1316$ Jemna (Jemna; NGŚ IV, 95), 1228, 1239 Rudno, 1318 Raudnitz (Rudnica; NGŚ XII, 18-19), 1219 Ostrossouichi, 1334 Wygandisdorf (Ostroszowice; NGŚ IX, 107), 1305 Bela superior (Bielawa Górna ${ }^{54}$ ),

48 Por. stczes. imię Chotěn z Chotěbor, Chotěslav itp., J. Pleskalová, Tvořeni nejstaršich českých osobnich jmen, Brno 1998, s. 95, 51 oraz nazwę miejscową Choceň (1227 Hocen, 1341 Kotzen, MJČ II, 95).

49 A. Barciak, op. cit., s. 58. Okolica Prudnika należała do czeskich i morawskich rodów do 1337 roku. A.B. Weltzel, Historia miasta Prudnika na Górnym Ślasku, Opole 2005.

${ }^{50} \mathrm{CDB}, \mathrm{t} .5 / 1, \mathrm{nr} 335$.

51 J. Mezník, Dějiny národu českého v Moravě (Nárys vývoje národního vědomí na Moravě do poloviny 19. století), „Český časopis historický” 88, 1990, s. 37-38.

52 J. Malicki, Język polski i czeski na potudniowej rubieży Dolnego Śląska, „Rozprawy Komisji Językowej [WTN]" 33, Wrocław 2006, s. 281-287.

${ }^{53}$ Liber fundationis..., Registrum Wratislaviense.

54 Ibidem. 
1305 Bistricza (Bystrzyca; NGŚ I, 134) ${ }^{55}$. Zapisy nazw rodzimych, które odnoszą się do miejscowości w paśmie od Vidnavy po Bielawę, a nawet dalej wzdłuż Czeskich Gór (Montana Bohemie) $)^{56}$ i występują obok nazw niemieckich, świadczą o rozszerzeniu zasięgu śląskiej polszczyzny w XIII i może na początku XIV wieku. Identyfikację ze śląską wspólnotą polskojęzyczną uzasadnia kościelna i polityczna przynależność tego obszaru i kierunek rozwoju strefy osiedlenia ${ }^{57}$. Potwierdzają ją nie tylko częste w Księdze henrykowskiej kwalifikatory nazw typu ,dicitur aput Polonos”, ,in polonico [dicitur]”, ,in polonico [vocatur]"58, ale (w odniesieniu do księstwa nyskiego) także wzmianki w dokumentach ${ }^{59}$. Cechy typowe dla języka polskiego (TroT, TloT, o z ps. e, samogłoski nosowe zapisane jako an, en, zachowanie $g$, substytuty $d z$ i $d z ́$ ) wykazują zapisy: 1202 Wzurucona, 1230 Wrocina - Zwrócona (Zwrócona; NGŚ XVI), około 1300 Bronissowicz (Broniszowice; NGŚ I, 98), około 1300 Blothnicza - Btotnica (Błotnica; NGŚ I, 63), 1288 Camon - Kamiona (Kamienica; NGŚ IV, 129), 1207 Strankawa Strakowa (Strąkowa; NGŚ XIII, 104), 1284 Prilank (Przełęk; NGŚ XI, 51), 1284 Swacow, XIII wieku Swentow - Świętów (Świętów Polski; NGŚ XIV, 54), 1210 Grochowischa - Grochowiska (Grochowiska; NGŚ III, 103), 1284 Glina - Glina (Hlína, zanikła osada; MJMS I, 258, por.), 1296 Gosena, 1320 Gostycz - Gościce (Gościce/Horní Hoštice; NGŚ III, 73; MJMS I, 284), 1273 Busov-Budzów (Budzów; NGŚ I, 121), 1296 Vyeszez - Ujezdziec (Ujeździec; NGŚ XIV, 128).

Nietypowe zapisy $d$ ' $i t$ ' pojawiają się między innymi w zapisach hybrydalnych: 1263 Budissow (Budzów; NGŚ I, 121), 1316 Radissindorf (Radziszyn, część Jemnej; NGŚ IV, 95), 1320 Slawatindorf (Sławęcin; NGŚ XII, 1318 Stiborndorf (Ścibórz; NGŚ XIV, 12) ${ }^{60}$.

Na przeciwległej stronie gór Złotych, Bardzkich i Sowich — w Kotlinie Kłodzkiej — od połowy XIII wieku przebiegała intensywna kolonizacja niemiecka. Jednocześnie zagęściła się i rozszerzyła również sieć osad czeskich ${ }^{61}$. Dla ewentualnych kontaktów językowych ze wspólnotami śląskimi największe znaczenie miało stare skupisko w centrum kotliny, ciągnące się aż do granicznego

55 Zob. R. Zuber, Osídlení Jesenicka do počátku 15. století, Opava 1972, s. 30-35. Księga henrykowska informuje o przełamaniu granicy osiedlenia, jaką wyznaczała przesieka już w drugiej ćwierci XIII wieku. Por. Księga henrykowska, przeł., wstęp i oprac. R. Grodecki, Wrocław 1984, s. 68, 74-79, 223, 229-232.

${ }^{56}$ Księga henrykowska..., s. 223.

57 Jeszcze w XVIII wieku w okolicach Jawornika można było spotkać sędziwych wieśniaków mówiących tylko polską gwarą. Por. L. Perich, Slezsko. Přehled národnostního vývoje, Praha 1945, s. 82, przyp. 60.

${ }^{58}$ Księga henrykowska..., s. 217, 227, 230.

${ }^{59}$ Por. J. Malicki, Język polski i czeski..., s. 286.

${ }^{60}$ Księga henrykowska..., s. 282-284, 287.

${ }^{61}$ Por. S. Sochacka, Związki toponimii Ziemi Kłodzkiej z językiem i historia Czech, „Bohemistyka” 2014, nr 1, s. 48-63; J. Malicki, Proměnlivé osudy kladských zemépisných jmen, s. 6062, mapa, s. 64-65. 
Barda $^{62}$. Tezy o polsko-czeskiej strefie kontaktowej w okolicach starego szlaku łączącego Śląsk i Czechy przez Ziemię Kłodzką — od Barda po Kamieniec Ząbkowicki i dalej na północ (falsum 1207 Zadel, 1237 Zadlno, Sadlno, NGŚ XII, 48; 1228 Ternav, Tarnów ${ }^{63}$ - nie dało się jak dotąd w pełni przekonująco uzasadnić historycznym materiałem toponimicznym, jednak położenie, zmienna przynależność polityczna tych obszarów do początku XII wieku, a nawet wzmianki źródłowe stanowią przesłanki uprawdopodobniające istnienie takiej strefy ${ }^{64}$.

Właściwa rozbudowa wschodnioczeskiej strefy osiedlenia rozpoczęła się w XIII wieku na wschód od Ziemi Kłodzkiej i na południe od Broumovskich stěn, czyli w znacznej odległości od południowego skraju polskiego osadnictwa na Dolnym Śląsku. Na niemal bezludnej połaci Krkonošskiego podhůří na północ od Jaroměřa i Miletína w drugiej połowie XII wieku istniały tylko nieliczne osady, między innymi Dvůr Králové (1270 Curia; MJČ I, 517) i Úpa (Trutnov, 1260 Vpa; MJČ IV, 391). Od początku XIII wieku wzmiankowano czeskie osady wokół benedyktyńskiego klasztoru polickiego na terenach nad Metują i Drzewiczem: 1213 Policz - Policě (Police n. Metují; MJČ III, 426), 1256 Pozdesin - Pozděšín (Bohdašín; MJČ I, 109), 1304 Rokytnik, 1307 Rokitnik - Rokytník (Starý Rokytník; MJČ III, 582), 1321 Starkow - Stárkov (Stárkov; MJČ IV, 163), 1358 Bezdiekow - Bezděkov (Bezděkov nad Metují; MJČ I, 74), 1395 Bukowicze - Bukovice (Bukovice; MJČ I, 237). Trzynastowieczne czeskie zapisy nazw z obszaru leżącego na północ od Broumovskich stěn świadczą o ówczesnej penetracji tych okolic, do szerzej zakrojonej czeskiej akcji osadniczej w tym pogranicznym rejonie nie doszło. Można tylko przypuszczać, że czasowo istniało tu kilka niewielkich czeskich osad. Nazwy Březnicě, Křinicě i Božanov, odnoszące się wpierw do potoków, dopływów Ścinawki, stały się nazwami miejscowymi i trwały obok nazw nowych osad niemeckich: Martinsdorf, Weckersdorf, Bartsdorf, odróżniając (starsze) części wsi ${ }^{65}$.

W drugiej połowie XIII wieku rozpoczęła się także intensywniejsza kolonizacja w kierunku Bramy Lubawskiej66. Obok niemieckich nazw zakładanych tu wówczas osad pojawiały się nazwy osad czeskich: 1297 Alberonis villa - Albersdorf? (Okrzeszyn; NGŚ IX, 21 lub Dolní Albeřice; MJČ I, 7), 1297 Bernarthicz - Bernartice (Bernartice; MJČ I, 56), 1289 Blassdorf - Blassdorf (Błażejów; NGŚ I, 62), 1260 Brusnicz - Brusnice (Hajnice; MJČ I, 190), 1260 Debrny, Do-

62 Ibidem.

63 SUb I, nr 290.

64 Por. J. Malicki, Język polski i czeski..., s. 282-284.

65 Por. E. Skála, Jazyková situace v Čechách v rozmezi let 993-1322, [w:] Milénium břevnovského kláštera (993-1993). Sborník statí o jeho významu a postavení v dějinách, red. I. Hlaváček, M. Bláhová, Praha 1993, s. 169. Szerzej J. Malicki, K onymickým stopám..., s. 10, 14-16, gdzie rownież odsyłacze do literatury tego zagadnienia.

66 Zob. O. Wolf, Ad forum et ad iudicum: Ke genezi lokačního osídlení w podhưrí Krkonoš a Kamenných hor, [w:] Pod Libavským sedlem. Sborník. Pod Przełęczą Lubawska. Księga zbiorowa, red. V. Wolf, V. Málek, Trutnov 2010, s. 41-58. 
brni, 1297 Doberni - Debrný (Debrné; MJČ I, 328), 1260 Lubcze, Lubech, 1297 Lubecz - Lubeč (Libeč; MJČ II, 569), 1260 Lysa - Lysá (zanikła wieś; MJČ II, 702), 1297 Olesna - Olešná (Zlatá Olešnice; MJČ III, 270), 1260 Ostrosniche - Ostrožnice (zanikła wieś; MJČ III, 301), 1260 Poretch - Pořičí (Poříčí, cz. Trutnowa; MJČ III, 440), 1260 Hubrocz siue Wogschi - (S)vojši (Bojiště; MJČ I, 701 por. ${ }^{67}$ ), 1260 Boletim - Voletin (Voletiny; MJČ IV, 603-604).

Osadnictwo kierowane z Czech w drugiej połowie XIII wieku dotarło na północ od Zaworów i Lasockiego Grzbietu Karkonoszy na skraj Kotliny Kamieniogórskiej ${ }^{68}$. Na nieudanej fundacji krzeszowskiego klasztoru benedyktynów z czeskich Opatovic (1242 Cressobor, 1249 Crosofbor, 1254 Cresowbor - Krzesów Bór/Křěsóv Bor, Krzeszów; NGŚ VI, 59-60) możliwości czeskiej ekspansji osadniczej i językowej się wyczerpały. O istotnym styku językowym trudno tu mówić ze względu na bardzo nieliczne dane ${ }^{69}$. Najpewniej polskie osadnictwo nie wykroczyło trwale na południe od Świn.

Podsumowując przedstawiony tu materiał i nawiązując do wcześniej już opublikowanych ustaleń ${ }^{70}$, można pokusić się o wnioski natury geolingwistycznej, onomastycznej i historycznojęzykowej. Przytoczone przykłady rodzimych nazw miejscowych zapisanych w dokumentach dotyczących zasiedlenia strefy gór i pustek między Śląskiem a Czechami i Morawami stanowią materiałowe uzasadnienie wytyczenia językowego pogranicza polsko-czeskiego w średniowieczu oraz lokalizacji odcinków, gdzie możliwe były wzajemne oddziaływania obu języków. Te dokumentowe zapisy toponomastyczne to świadectwa wycinkowe $-\mathrm{z}$ jednej strony nieuwzględniające nazw niedochowanych w źródłach oraz zapisanych dopiero znacznie później, z drugiej zwodnicze, jeśli staną się podstawą zbyt daleko idących uogólnień areałowych, należy bowiem pamiętać, że oprócz nazw rodzimych o zasięgu ówczesnych oddziaływań językowych mówią też niemieckie nazwy osad zasiedlonych przez kolonistów. Wreszcie materiałem ilustrującym te zjawiska są również inne nazwy geograficzne - hydronimy i oronimy oraz antroponimy, których rozpatrzenie wymaga nie tylko pogłębionego badania kontekstów źródłowych, ale również kontrastywnej analizy onomastycznej na tle ówczesnych tendencji w imiennictwie czeskim i polskim. Na konieczność

${ }^{67}$ Postać Vojši (z nazwy os. Svojše) rekonstruuje V. Wolf, O některých mistnich jménech na Trutnovsku, „Krkonoše - Podkrkonoší” 7, 1983, s. 309-326; por. MJČ IV, 261.

68 J. Wolf, Osídlení kraje na česko-slezském pomezi vychodně od Krkonoš v 2. pol. 13. stol., [w:] I Międzynarodowa Konferencja Człowiek i środowisko w Sudetach, red. M. Boguszewicz, A. Boguszewicz, D. Wiśniewska, Wrocław 2000, s. 148-149.

${ }^{69}$ Kolejne zapisy nazw z elementami rodzimymi pochodzą z końca XIII i z XIV wieku: 1287 Rysindorf, 1338 Ruzsindorf - Rusin, Rusinów (Raszów, NGŚ XI, 1140); 1292 Blasei dorf - Błażejów (Błażkowa Dolna, NGŚ I, 62), 1284 Lubavia, 1293 Liebau, 1328 Lubavia - Lubawa (Lubawka, NGŚ VII, 23). Por. Z. Wielgosz, Wielka własność cysterska w osadnictwie pogranicza Śląska i Wielkopolski, Poznań 1964, s. 19-30; J. Malicki, Język polski i czeski..., przyp. 37, s. 286; idem, K onymickým stopám..., s. 9.

70 J. Malicki, Język polski i czeski... 
takiego poszerzenia perspektywy badawczej zwracano niejednokrotnie uwagę, uwzględniły ten aspekt między innymi prace Rudolfa Šrámka i Henryka Borka. Autorzy ci zwrócili też uwagę na wiele analogii typologicznych i historycznych w toponomastykonie po obu stronach granicy śląsko-morawskiej ${ }^{71}$. Nazewnicze powinowactwa i pokrewieństwa wskazują zapewne na wcześniejszy stan, zarysowany być może pod koniec epoki plemiennej.

Spory o pierwszeństwo polszczyzny czy czeszczyzny na tych obszarach pogranicza wydają się jałowe. Dotyczą X-XII wieku, a więc okresu w dziejach obu języków propedeutycznego (období pračeské, okres prapolski), kiedy oba języki nie były jeszcze ostatecznie wyodrębnione - ani pod względem właściwości systemowych, ani też pod względem areałowym. Pod koniec XII i w XIII wieku obszar Śląska był, jak ukazały prace Bogusława Dunaja i Małgorzaty Sulisz ${ }^{72}$, dzielnicą językowo dość mocno zintegrowaną z pozostałymi dzielnicami Starej Polski. B. Dunaj, osobno analizując zastrzeżenia odnośnie do zapisów, które odbiegają od modelowych cech języka, doszedł do wniosku, że w tym czasie nie ustał czeski wpływ na język polski i że zaznaczył się pożyczkami graficznymi częstymi zwłaszcza w źródłach z południowej Polski ${ }^{73}$. W rozpatrywanym przeze mnie materiale $\mathrm{z}$ pasma pogranicznego ten wpływ jednak zaznaczył się stosunkowo słabo - uwidoczniła się przede wszystkim tendencja do graficznego rozróżniania cech fonetycznych obu języków w obrębie istniejących już podziałów politycznych — zasięgów władzy Przemyślidów i Piastów.

W XIII wieku, kiedy doszło na Śląsku do przebudowy wcześniejszego stanu zasiedlenia, kierunek integracji językowej w poszczególnych rejonach pogranicza nie był jeszcze przesądzony. Systematyczny rozwój można zaobserwować na skraju mniej lub bardziej zwartego obszaru osadniczego powstałego z dawnych plemiennych skupisk osadniczych. Tworząc mapę ówczesnych zapisów nazw miejscowych na obszarze styku Śląska, Czech i Moraw, zauważamy na relatywnie długim odcinku między Ostrawicą a Prudnikiem kurczenie się dystansu między zasięgami siedzib użytkowników ówczesnej polszczyzny i czeszczyzny. Własną (małą) dynamiką rozwoju charakteryzowały się mniejsze skupiska osadnicze, wyspowo rozmieszczone poza zasięgiem relatywnie zwartego osadnictwa, sięgające jeszcze czasów plemiennych (Ziemia Kłodzka) i nowsze, powstałe już w organizmach politycznych Przemyślidów czy Piastów (rejon Osobłogi, Kotlina Kamieniogórska).

Na dawnym obszarze golęszyckim i zapewne również w mniejszej strefie kontaktowej zlokalizowanej na północ od Ziemi Kłodzkiej lokalne ruchy migracyjne i sąsiedztwo szlaków handlowych mogły prowadzić do przenikania się innowacji i nawarstwiania wpływów z północy i południa. Rozwój typowy dla jednego z języków zakłócała również zmienność wpływów politycznych (wpływ wielkomorawski, uzależnienie od Czech $\mathrm{w} \mathrm{X}$ wieku, ekspansja polska na po-

\footnotetext{
71 Por. R. Šrámek, Soustava ..., s. 369-370, 393-396; H. Borek, Opolszczyzna ..., s. 176-184.

72 B. Dunaj, Język polski najstarszej doby; M. Sulisz, op. cit.

73 B. Dunaj, Zapożyczenia czeskie..., s. 29, 34, 37.
} 
łudnie w czasach Chrobrego, okresowa przynależność południowych rubieży Śląska do Czech w XI i XII wieku, wyniszczenie obszarów między Kłodzkiem i Kamieńcem, Hradcem i Raciborzem, wreszcie włączenie dawnej prowincji golęszyckiej do Moraw). W ślad za zmianami przynależności państwowej szły również zmiany zasięgu wpływów czeskiego i polskiego Kościoła, co zapewne sprzyjało powstawaniu zjawisk przechodnich. Zmiany zasięgów władzy politycznej i kościelnej wywoływały okresową transmisję innowacji z jednego centrum oraz izolację na wpływy drugiego. Nie można więc wykluczyć wczesnego pojawienia się niektórych innowacji czesko-słowackich na północ od linii Sudetów ${ }^{74}$.

Te dobre warunki do przenikania się wpływów językowych w rejonie między Opawą i Krnovem a Głubczycami potwierdzają tylko nieliczne zapisy nazw miejscowych, których grafika wskazuje na łączenie w warstwie fonetycznej wpływów północy i południa. Stabilniejsza jest grafika modelowa, czeska, a więc wpływ kancelaryjny czy wpływ języka ośrodka władzy. Podobny wpływ obserwujemy w grafice nazw lokalizowanych na dawnej rubieży golęszycko-opolskiej. Zapisy oddają polskie cechy fonetyczne, ale nielicznych pojawiających się odchyleń od modelu (brak przegłosu $\check{e}>a$, substytucja $a$ za $e$ ) nie można tu zdecydowanie uznać za rezultat wpływu czeskiego.

Mniej pewne niż na dawnym obszarze golęszyckim jest wczesne (XII-XIII wieku) oddziaływanie z południa na dialekt społeczności zamieszkującej skupisko osadnicze nad Olzą i górną Wisłą. Szersze otwarcie na wpływy czeskie nastąpiło tu zapewne w drugiej połowie XIII wieku wraz z rozwojem osadnictwa nad Ostrawicą, kiedy wytwarza się tu bezpośredni styk obu języków. W przytoczonym materiale $\mathrm{z}$ księstwa cieszyńskiego wpływ czeski uwidacznia się minimalnie, niewielkie są również odchylenia od modelowych czeskich zapisów po morawskiej stronie Ostrawicy.

Do bezpośredniego styku obu języków dochodziło pod koniec XIII wieku w paśmie od Ostrawicy po Prudnik. Słabnące w okolicach Prudnika wpływy czeskie sąsiadowały od zachodu z dość ekspansywną jeszcze w XIII/XIV wieku śląską polszczyzną w księstwie nyskim i dalej na środkowym odcinku Przedgórza Sudeckiego. W materiale nazewniczym pojawiły się tu sporadycznie bohemizmy graficzne ${ }^{75}$ typowe dla części śląskich dokumentów tego okresu, a więc świadczące o ówczesnym czeskim wpływie kulturowym. W strefie położonej wokół szlaku z Czech na Śląsk od Przełomu Bardzkiego w kierunku Kamieńca i Niemczy późniejsze zmiany osadnicze zatarły pierwotny obraz stosunków językowych, zapisy toponimów nie przysparzają niepodważalnych danych o kontaktowym czy przejściowym charakterze tego obszaru. W pewnym stopniu mogą tu posłużyć źródła narracyjne i dokumentowe.

Zanim na skutek integracji językowej starych i nowych mieszkańców rozproszyły się wcześniejsze słabe oddziaływania polsko-czeskie w paśmie pograni-

\footnotetext{
74 Por. J. Malicki, Zagadnienie morawskiej i czeskiej...

75 J. Malicki, Język polski i czeski..., s. 282-284.
} 
cza, w XIII i XIV wieku kontakty języka polskiego i czeskiego musiały nakładać się na tym obszarze na kontakty niemiecko-polskie i niemiecko-czeskie. Jednym ze skutków była też zmienność nazewnicza, powstawanie nazw o mieszanym charakterze polsko-niemieckim i czesko-niemieckim i upowszechnianie nowych modeli nazewniczych w miejscowej toponimii. Dynamiczny rozwój wspólnot niemieckojęzycznych, pod względem językowym jeszcze bardzo niejednorodnych, był czynnikiem izolacji. Znaczna część obszaru językowego pogranicza polsko-czeskiego stała się obszarem niemieckojęzycznym. Rozproszone wysepki pierwotnie polsko- i czeskojęzyczne rychło wchłonął rozwijający się niemiecki obszar gwarowy potomków kolonistów, co ostatecznie zadecydowało o lokalnym typie polsko-czeskiego sąsiedztwa językowego.

\section{Bibliografia}

\section{Opracowania}

Bakala J., Národnostní a politický vývoj Slovanů v opavském a těšinském Slezsku, Opava 1969, s. 97-99.

Balhar J., Slezská nářeční skupina, [w:] Encyklopedický slovník češtiny, red. P. Karlík, M. Nekula, J. Pleskalová, Praha 2002.

Barciak A., Czechy a ziemie potudniowej Polski w XIII oraz w poczatkach XIV wieku, Katowice 1992.

Bąk S., Mowa polska na Śląsku, Wrocław 1974.

Bělič J., K otázce pomezních nářeči, „Slovo a slovesnost” 16, 1955, s. 129-139.

Boguszewicz A., Z badań nad przemianami osadnictwa w Sudetach Ślaskich w XII-XIII w., [w:] Człowiek i środowisko w Sudetach, red. M. Boguszewicz, A. Boguszewicz, D. Wiśniewska, Wrocław 2000, s. 151-168.

Borek H., Górny Śląsk w świetle nazw miejscowych, Opole, 1988.

Borek H., Opolszczyzna w świetle nazw miejscowych, Opole 1972.

Čornejová M., Ke grafice bohemik 10.-12. století, „Sborník prací Filozofické fakulty brněnské univerzity, řada A, Lingustica brunensia" 2005, s. 139-141.

Damborský J., Czeszczyzna w pasie przygranicznym, [w:] Konsekwencje sasiedztwa polsko-czeskiego dla rozwoju języka i literatury, red. T.Z. Orłoś, J. Damborský, Wrocław 1997, s. 33-40.

Damborský J., Gwara czesko-cieszyńska, [w:] Z badań porównawczych języków i dialektów słowiańskich i niesłowiańskich na ziemiach nadodrzańskich, red. J. Brzeziński, Zielona Góra 1992, s. 71-75.

Damborský J., Podzwonne dla sporów o laszczyznę, [w:] Podzwonne dla granic. Polsko-czeskie linie podziałów i miejsca kontaktów w języku, literaturze i kulturze, red. J. Lipowski, D. Żygadło-Czopnik, Wrocław 2009, s. 343-351.

David J., Macha P., Názvy míst. Pamět', identita, kulturní dědictví, Brno 2014.

Dejna K., Dialekty polskie, Wrocław-Warszawa-Kraków 1993.

Dejna K., Polsko-laskie pogranicze językowe, t. 1-2, Łódź 1951-1953.

Dubisz S., Rozwój polskiego systemu fonologicznego, [w:] Studia z historii języka polskiego, red. W. Kupiszewski, Warszawa 1994, s. 9-19.

Dunaj B., Język polski najstarszej doby piśmiennej (XII-XIII w.), Kraków 1975.

Dunaj B., Zapożyczenia czeskie w polszczyźnie XII-XIII w., „Zeszyty Naukowe UJ 451, Filologia. Prace Językoznawcze” 52b, 1976. 
Góral B., Czym jest pejzaż językowy (linguistic landscape), [w:] Język w poznaniu 2, red. K. Juszczyk, B. Mikołaczak, J. Taborek, W. Zabrocki, Poznań 2011, s. 41-60.

Havránek B., Kobecným vývojovým zákonistem spisovných jazyků, [w:] idem, Studie o spisovném jazyce, Praha 1963, s. 92-94.

Havránek B., K otázce mezislovanských vztahů spisovných jazyků, [w:] idem, Studie o spisovném jazyce, Praha 1963, s. 332-335.

Havránek B., Nářeči česká, [w:] Československá vlastivěda. Řada 1., t. 3. Jazyk, Praha 1934.

Hosák L., Středověká kolonizace Osoblažska, „Časopis Slezského muzea” 14, 1965, seria B: Vědy historické.

Hujer O., Vývoj jazyka československého, [w:] Československá vlastivěda. Řada t 3. Jazyk, Praha 1934.

Kellner A., Východolašská nářečí, t. 1-2, Brno 1946-1949.

Komárek M., Nástin fonologického vývoje českého jazyka, Praha 1982.

Kopečný F., Ještě poznámka k problému česko-polské jazykové hranice, „Slezský sborník” 54, 1956, s. 547-548.

Kopečny F., K jazykové přislušnosti Holasiců, „Slezský sborník” 60, 1962, s. 122-125.

Kouřil P., Severni predpoli moravské brány a zásah velkomoravský, [w:] Ślask i Czechy a kultura wielkomorawska, red. K. Wachowski, Wrocław 1997.

Kouřil P., Prix D., Wihoda M., Hrady českého Slezska, Brno-Opava 2000.

Ksiega henrykowska, przeł., wstęp i oprac. R. Grodecki, Wrocław 1984.

Lamprecht A., K otázce lašských nářeči, „Slovo a slovesnost” 16, 1955, s. 140-146.

Leciejewicz L., Stowianie zachodni. Z dziejów tworzenia się średniowiecznej Europy, Wrocław 1989.

Malicki J., Język polski i czeski na poludniowej rubieży Dolnego Śląska, „Rozprawy Komisji Językowej [WTN]" 33, Wrocław 2006, s. 281-287.

Malicki J., K onymickým stopám jazykové historie okoli Broumovských stěn, „Východočeské listy historické" 34, 2017, s. 16-19.

Malicki J., Proměnlivé osudy kladských zeměpisných jmen, predevším mistnich, [w:] E. Semotanová et al., Kladsko. Historickogeografický lexikon, Praha 2015, s. 64-65.

Malicki J., Zagadnienie morawskiej i czeskiej obecności na wczesnośredniowiecznym Ślasku jako przestanka dla lingwistyki historycznej regionu, „Śląski Kwartalnik Historyczny Sobótka” 72, nr 1, 2017.

Mezník J., Dějiny národu českého v Moravě (Nárys vývoje národního vědomí na Moravě do poloviny 19. století), „Český časopis historický” 88, 1990, s. 37-38.

Mrózek R., Nazwy miejscowe dawnego Śląska Cieszyńskiego, Katowice 1984.

Perich L., Slezsko. Přehled národnostního vývoje, Praha 1945.

Przybytek D., Nazewnictwo miejscowe źródtem $w$ regionalnych badaniach geograficzno-historycznych Ślaska, [w:] Nazwa dokumentem przeszłości regionu, red. J. Nowosielska-Sobel, G. Strauchold, W. Kucharski, Wrocław 2010, s. 118-120.

Rajman J., Jarosław/Kazimierz i Woszczyce - pierwsze fundacje cysterskie w księstwie opolsko-raciborskim (koniec XII i pierwsza połowa XIII wieku), „Śląski Kwartalnik Historyczny Sobótka" 53, 1998, z. 1-2, s. 1-18.

Rospond S., Patronimiczne nazwy miejscowe na Ślasku, Wrocław 1964.

Rospond S., Problematyka pierwotnych stosunków polsko-czeskich w Bramie Morawskiej, „Kwartalnik Opolski" 9, 1965, z. 3, s. 38-40.

Rospond S., Z badań nad stosunkami językowymi polsko-czeskimi do XVI w., „Rozprawy Komisji Językowej WTN" 4, 1963.

Siatkowski J., Czesko-polskie kontakty językowe, Warszawa 1996. 
Skála E., Jazyková situace v Čechách v rozmezi let 993-1322, [w:] Milénium břevnovského kláštera (993-1993). Sborník statí o jeho významu a postavení v dějinách, red. I. Hlaváček, M. Bláhová, Praha 1993.

Sochacka S., Pogranicze polsko-czeskie w świetle nazw miejscowych (analiza wpływów czeskich), [w:] Stosunki polsko-czeskie, red. M. Lesz-Duk, R.K. Zawadzki, Częstochowa 1997, s. 148149.

Sochacka S., Zwiazki toponimii Ziemi Kłodzkiej z językiem i historia Czech, „Bohemistyka” 2014, nr 1, s. 48-63.

Šrámek R., Soustava mistnich jmen na severovýchodni Moravě a ve Slezsku, „Slezský sborník” 63, 1965, s. 368-397.

Stieber Z., Geneza gwar laskich, Kraków 1934.

Stieber Z., Historyczna i wspótczesna fonologia języka polskiego, Warszawa 1966.

Stieber Z., Zarys gramatyki porównawczej języków słowiańskich, Warszawa 1989, s. 28-59.

Sulisz M., Staropolska fonetyka w świetle materiału onomastycznego do XIV w., Wrocław 1976.

Třeštík D., Počátky Přemyslovcü, Praha 2008.

Tyszkiewicz J., Z badań nad wczesnośredniowiecznym osadnictwem górnego dorzecza Odry. Brzmienia pierwotne i umiejscowienie Lupiglaa i Golensizi tzw. Geografa Bawarskiego, [w:] Studia z dziejów osadnictwa, red. A. Płachcińska, t. 1, Warszawa 1963, s. 1-71.

Urbańczyk S., Czesko-polska granica etniczna $w$ świetle nazw miejscowych, „Sprawozdania z Czynności i Posiedzeń Polskiej Akademii Umiejętności” 47, 1946, nr 1.

Urbańczyk S., Geografa Bawarskiego Lupiglaa-Ghupogłowy, „Slavia” 24, 1957.

Urbańczyk S., Rozwój języka narodowego, [w:] idem, Szkice z dziejów języka polskiego, Warszawa 1968.

Urbańczyk S., W sprawie polskiego języka literackiego, [w:] idem, Szkice z dziejów języka polskiego, Warszawa 1968.

Walczak B., Komu zawdzięczamy polski język literacki, [w:] Język a chrześcijaństwo, red. I. Bajerowa, M. Karpluk, Z. Leszczyński, Lublin 1983, s. 23-42.

Walczak B., Geneza polskiego języka literackiego, „Teksty Drugie: teoria literatury, krytyka, interpretacja" 27, 1994, nr 3, s. 35-47.

Weltzel A.B., Historia miasta Prudnika na Górnym Śląku, Opole 2005.

Wielgosz Z., Wielka własność cysterska w osadnictwie pogranicza Śląska i Wielkopolski, Poznań 1964.

Wolf J., Osídleni kraje na česko-slezském pomezi vychodně od Krkonoš v 2. pol. 13. stol., [w:] I Międzynarodowa Konferencja Człowiek i środowisko w Sudetach, red. M. Boguszewicz, A. Boguszewicz, D. Wiśniewska, Wrocław 2000, s. 148-149.

Wolf V., Ad forum et ad iudicum: Ke genezi lokačního osídlení w podhůř́ Krkonoš a Kamenných hor, [w:] Pod Libavským sedlem. Sbornik. Pod Przełęcza Lubawska. Księga zbiorowa, red. V. Wolf, V. Málek, Trutnov 2010, s. 41-58.

Wolf V., O některých mistních jménech na Trutnovsku, „Krkonoše - Podkrkonoši” 7, 1983, s. 309-326.

Zabrocki L., Zasięgi językowego magazynowania nazw jednostkowych, [w:] Symbolae philologicae in honorem Vitoldi Taszycki, red. S. Hrabec, S. Jodłowski, M. Karaś, J. Kuryłowicz, J. Safarewicz, F. Sławski, L. Zabrocki, Wrocław 1968, s. 416-424.

Zuber R., Osídlení Jesenicka do počátku 15. století, Opava 1972.

\section{Źródła}

Codex diplomaticus et epistolaris Moraviae, t. 1, red. A. Boček, Olomutii 1836, nr 307.

Kodeks dyplomatyczny Śląska, t. 1, wyd. K. Maleczyński, Wrocław 1956, nr 55, 67, 77, 78.

Schlesisches Urkundenbuch, t. 1, red. H. Appelt, Wien-Köln-Graz, 1963-1971, nr 284. 


\title{
Cytowane słowniki toponomastyczne
}

MJČ -A. Profous, Mistní jména v Čechách, jejich vznik, pưvodní význam a změny, t. 1-4, Praha 1947-1954; t. 5 J. Svoboda, V. Šmilauer et al., Praha 1960.

MJMS — L. Hosák, R. Šrámek, Místní jména na Moravě a ve Slezsku, t. 1-3, Praha 1970, 1980.

NGŚ - Stownik etymologiczny nazw geograficznych Śląska, t. 1, red. S. Rospond, Warszawa-Opole 1970, t. 2-4 red. S. Rospond, H. Borek, Warszawa-Wrocław 1985-1987, t. 5-8, red. S. Sochacka, Wrocław 1991-1997, t. 9-12, red. S. Sochacka, Opole 1999-2005.

\section{Polish and Bohemian toponyms in the face of the emergence and development of the Polish-Bohemian language border in the Middle Ages}

\begin{abstract}
Summary
An analysis of the material presented in the article (geographical names, hydronyms, oronyms as well as anthroponyms) makes it possible to draw geolinguistic, onomastic and historical-linguistic conclusions concerning the Polish-Bohemian language borderland (between Silesia, Moravia and Bohemia) in the Middle Ages and to establish the areas in which the two languages could influence each other. In the 12th century, Silesia was strongly linked linguistically to the other provinces of former Poland. In the 13th century, direct contact between the Polish and Czech languages occurred in an area from Ostravice to Prudnik. In the 13th and 14th centuries contacts between the two languages in the area overlapped with German-Polish and German-Bohemian contacts. This resulted in changes of names, mixed names, spread of new naming models. Part of the language area of the Polish-Bohemian borderland became a German-speaking area. This determined the local nature of the Polish-Czech or Polish-Bohemian linguistic neighbourhood.
\end{abstract}

Keywords: language borderland, Silesian dialects, Silesian-Moravian dialects, toponymy, Bohemian and Polish toponyms 